\title{
PENGEMBANGAN MODEL LATIHAN GERAK JURUS TUNGGAL BAKU PENCAK SILAT PADA SISWA EKSTRAKULIKULER DI SMP 2 N PLUMBON
}

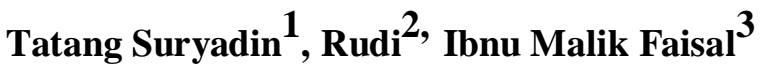 \\ Universitas Majalengka, Indonesia \\ email: ttngsuryadin@gmail.com,rudi@unma.ac.id,ibnumalik_faisal@gmail.com
}

\begin{abstract}
ABSTRAK. Penelitian ini mengkaji pengembangan model latihan gerak jurus tunggal baku pencak silat. Metode penelitian ini adalah penelitian pengembangan. Pengumpulan data dengan menggunakan kuesioner yang diperoleh dari evaluasi dosen dan pelatih pencak silat, uji coba kelompok kecil 10 siswa dan uji kelompok kecil 20 siswa. Data berupa hasil penilaian mengenai kulaitas produk, dan hasil pengisian kuesioner oleh siswa. Teknik analisis data yang digunakan adalah deskriptif persentase. Berdasarkan hasil analisis data pelatih pencak silat didapat rata-rata persentase 91,67\% (Kategori Sangat Baik) dan hasil analisis data evaluasi dosen ahli didapat rata-rata persentase 77,78\% (Kategori Baik). Artinya model latihan layak untuk digunakan. Hal ini berdasarkan hasil analisis data uji coba skala kecil 10 siswa didapat rata-rata persentase 77,50 \% (kategori baik). Selanjutnya hasil analisis data uji coba skala kecil 20 siswa didapat rata-rata persentase $77,08 \%$ (Kategori baik). Faktor yang menjadikan model ini dapat diterima siswa adalah dari hasil angket yang diisi oleh 10 siswa adalah $12,5 \%$ siswa menjawab sulit, 47,5\% siswa menjawab sedang dan $40 \%$ siswa menjawab mudah. Dari hasil angket yang di isi oleh 20 siswa adalah $10 \%$ siswa menjawab sulit, $50 \%$ siswa menjawab sedang dan $40 \%$ siswa menjawab mudah. Saran produk penelitian pengembangan ini dapat dijadikan sebagai alternatif model latihan gerak jurus tunggal baku. Penting dilakukan uji coba lanjutan yang terkait dengan model latihan ini.
\end{abstract}

Kata Kunci: Pengembangan; Jurus Tunggal; Pencak Silat

\section{Pendahuluan}

Dilihat dari sejarahnya pencak silat merupakan cara bertahan hidup manusia dari ganasnya alam masa itu. Hal ini sejalan dengan pendapat Mulyana (2013) yang mengungkapkan: Pencak silat yang mengutamakan beladiri sebetulnya sejak dahulu sudah ada karena dalam mempertahankan hidupnya manusia harus bertempur, baik manusia melawan manusia maupun melawan binatang buas. Pada waktu itu orang yang kuat dan pandai berkelahi mendapat kedudukan yang baik di masyarakat sehingga dapat menjadi kepala suku atau panglima raja. Lama-kelamaan ilmu berkelahi lebih teratur sehingga timbullah suatu ilmu beladiri yang disebut pencak silat.

Menurut Lubis dan Wardoyo (2013) mengungkapkan: "Kategori tunggal adalah kategori pertandingan pencak silat yang menampilkan seorang pesilat memperagakan kemahirannya dalam jurus baku tunggal secara benar, tepat, dan mantap, penuh penuh penjiwaan dengan tangan kosong dan bersenjata." Kategori tunggal dalam penampilannya 
merupakan gerakan-gerakan yang kompleks. Gerakan serangan, hindaran, sikap pasang yang tersusun dalam berbagai posisi tubuh.

Di SMP 2 N Plumbon pencak silat merupakan salah satu olahraga unggulan yang setiap tahunnya selalu memberikan kontribusi prestasi. Akan tetapi pada saat ini prestasi itu kian menurun dan cenderung tidak konsisten. Padahal program ini dari tahun ke tahun tidak mengalami perubahan yang signifikan. Penulis menduga penyebabnya adalah dalam penyampaian materi gerakan jurus tunggal baku yang belum sepenuhnya dikuasai oleh siswa.

Penguasaan gerakan jurus pencak silat secara sempurna harus dimulai sejak awal latihan, yakni ketika seorang pelatih mengajarkan kepada anak didiknya gerakan jurus pencak silat. Hal ini sejalan dengan pendapat Suryadin (2018) yang mengungkapkan: "Latihan yang baik adalah latihan yang mengkondisikan segala sesuatunya menyerupai dengan pertandingannya”. Pelatih yang terburu-buru dalam mengajarkan suatu teknik dengan tidak memperhatikan teknik gerak secara detail, hanya akan menciptakan seorang pesilat yang hanya hapal jurus saat mengikuti perlombaan. ataupun bila kebetulan anak tersebut berbakat, maka bakat yang dimiliki tidak tergali secara maksimal. Karena ia telah terbiasa melakukan gerakan jurus pencak silat yang salah. hal inilah yang menjadi permasalahan kelak sebab pembetulan gerakannya sulit dilakukan.

Model latihan jurus tunggal pencak silat yang digunakan saat ini adalah dengan cara diperagakan oleh pelatihnya untuk diikuti para siswa, karena cara tersebut dianggap simpel dan tidak rumit untuk diterima. Selain mengalami kesuliatan dalam menghafal gerakan, tidak sedikit juga pesilat yang tidak mengetahui kunci dari setiap gerakan dari materi-materi yang dipelajari. Hal ini dikarenakan belum berkembangnya model latihan atau pembelajaran khusus untuk pencak silat jurus tunggal baku.

Berdasarkan pengamatan peneliti, latihan atau pembelajaran jurus tunggal baku yang dilakukan di SMP 2 N Plumbon, terdapat beberapa permasalahan dalam latihan atau pembelajaran jurus tunggal baku. Gerakan jurus yang diperagakan siswa banyak yang salah, atau boleh dikatakan nilai kebenaran geraknya masih rendah. Sedangkan nilai kebenaran gerak ini adalah salah satu faktor yang menentukan dalam kemenangan. Selanjutnya sebagian siswa terlihat kurang antusias dalam belajar jurus tunggal baku, hal ini diindikasikan dengan banyak siswa yang tidak memperhatikan arahan dan koreksi dari pelatihnya. Dalam melakukan koreksi gerakan jurus pelatih hanya fokus pada urutan gerakan, padahal kebenaran setiap gerakan juga merupakan kunci dalam memperoleh nilai. Yang terakhir rangkaian gerakan jurus tunggal baku merupakan gerakan yang cukup sulit serta merupakan rangkaian gerakan yang panjang, dalam hal ini memerlukan koordinasi dan konsentrasi dalam latihan atau pembelajarannya. 
Untuk memperdalam bagaimana kondisi pembelajaran gerakan jurus tunggal baku di SMP $2 \mathrm{~N}$ Plumbon peneliti melakukan pengamatan dan wawancara dengan siswa. Berdasarkan pengamatan dan wawancara didapatkan beberapa fakta yang anatara laian : 1) Para siswa tidak mengetahui gerakan yang benar, intinya mereka memperagakan jurus tanpa diketahui kunci kebenaran gerakan tersebut. 2) Kejenuhan sering melanda para siswa yang diakibatkan cara latihan yang kurang bervariasi. 3) Gerakan jurus tunggal baku dirasa sulit dihapal dan diperagakan oleh para siswa yang sebagian baru mengenal gerakan jurus tunggal baku. 4) Sebagian siswa merasa tata cara pemberian koreksi/feedback yang dilakukan pelatih terkadang membingungkan.

Untuk menyampaikan gerakan jurus tunggal baku diperlukan model dan media dalam latihan atau pembelajaran. Rata-rata setiap perguruan silat mengajarkan aspek-aspek dalam pencak silat tersebut untuk mengejar prestasi dalam perlombaan, sehingga tidak memiliki banyak waktu untuk menyampaikan betapa pentingnya sebuah model latihan.

Berdasarkan permasalahan tersebut, terlihat bahwa kendala dalam proses belajarmengajar jurus tunggal baku pencak silat adalah : 1) Gerakan jurus tunggal baku merupakan gerakan yang memiliki kunci dari setiap gerakan jurusnya maka pembelajaran atau latihannya harus memperhatikan kuni tersebut. 2) Latihan atau pembelajaran yang sekarang dianggap monoton maka diperlukan pembaharuan dalam proses latihan atau pembelajarannya. 3) Gerakan jurus tunggal baku merupakan gerakan yang cukup sulit maka dalam latihannya diperlukan beberapa tahapan. 4) Pemberian koreksi atau umpan balik (feedback) dari guru/pelatih sebaiknya menggunakan cara-cara baru agar tidak terjadi gangguan secara psikologis yang berdampak pada menurunnya motivasi dalam latihan. Berdasarkan fenomena di atas peneliti tertarik untuk membuat sebuah pengembangan model latihan gerak jurus tunggal baku pencak silat pada siswa ekstrakulikuler di SMP 2 N Plumbon.

\section{Metode Penelitian}

Metode penelitian yang digunakan adalah Research and Development. Menurut Sugiyono (2018) mengungkapkan "Metode penelitian yang digunakan untuk menghasilkan produk tertentu, dan menguji keefektifan produk." Penelitian ini merupakan penelitian pengembangan yang bertujuan menghasilkan produk berupa pengembangan model latihan gerakan jurus tunggal baku. Dengan kata lain penelitian pengembangan atau penelitian developmental adalah penelitian yang mengadakan percobaan dan penyempurnaan. Penyusunan dan penyempurnaan model pembelajaran dilakukan dengan mengkonsultasikan dengan dosen ahli dan pelatih pencak silat. Pembelajaran diterapkan pada sampel kelompok kecil sebanyak 10 orang dan kelompok besar sebanyak 20 orang. Adapun isntrumen yang digunakan adalah 
kuisioner dengan pilihan: mudah, sedang dan sulit. Teknik analisis data yang digunakan adalah menggunakan teknik analisis deskriptif presentase. Sedangkan data yang berupa saran dan alasan dalam memilih jawaban dianalisis menggunakan teknik analisis kualitatif. Dalam pengolahan data, persentase diperoleh dengan rumus dari Sukirman, dkk (2004), yaitu: $F=f / N$ x $100 \%$.

\section{Hasil dan Pembahasan}

Revisi produk berdasarkan penilaian dari pelatih pencak silat / dosen ahli. adalah: Urutan latihan : latihan diarahkan terlebih dahulu pada penguasaan gerakan jurus tunggal baku yang benar dilanjutkan dengan latihan jurus tunggal baku yang mengarahkan pada pembentukan komponen kebugaran.

Memberi nama pengembangan model SIBAKOL IBFA (Simak Bayangkan, Koreksi Lakukan Ibnu Faisal) yang didalamnya urutan latihan jurus tunggal baku yang benar yaitu: a) Latihan lihat dan dengar selanjutnya sebutkan dan lakukan, b) Bayangkan gerakannya dan lakukan gerakan tersebut, c) Lihat Video dan temukan kesalahannya. d) Bayangkan dan hayati kemudian lakukan dengan cepat.

\section{Kelayakan Model secara Teorotik}

Kelayakan pengembangan model latihan jurus tunggal baku yang ditempuh adalah validasi dari pelatih pencak silat dan Dosen Ahli. Hasil evaluasi dan validasi pelatih silat dan dosen tersebut dapat disajikan dalam Tabel 1 berikut:

Tabel 1

Hasil Validasi Ahli Tentang Penilaian Latihan Gerak Jurus Tunggal SIBAKOL IBFA

\begin{tabular}{|c|c|c|c|c|c|c|c|c|c|}
\hline & & \multicolumn{4}{|c|}{ Pelatih Pencak Silat } & \multicolumn{4}{c|}{ Dosen } \\
\cline { 3 - 10 } N & Model & $\begin{array}{c}\text { Sistematik } \\
\text { a }\end{array}$ & Kesesuaian & $\begin{array}{c}\text { Daya } \\
\text { tarik }\end{array}$ & JML & $\begin{array}{c}\text { Sistemati } \\
\text { ka }\end{array}$ & Kesesuaian & $\begin{array}{c}\text { Daya } \\
\text { tarik }\end{array}$ & JML \\
\hline 1 & I & 3 & 3 & 2 & 8 & 2 & 3 & 3 & 8 \\
\hline 2 & II & 3 & 3 & 2 & 8 & 3 & 2 & 1 & 6 \\
\hline 3 & III & 3 & 3 & 3 & 9 & 3 & 2 & 2 & 7 \\
\hline 4 & IV & 3 & 2 & 3 & 8 & 2 & 2 & 3 & 7 \\
\hline \multicolumn{3}{|c|}{ Jumlah } & & 33 & \multicolumn{3}{c|}{ Jumlah } & 28 \\
\hline
\end{tabular}

Berdasarkan Tabel 4.1di atas dapat diperoleh gambaran bahwa secara keseluruhan dari penilaian pelatih pencak silat mencapai 33/36 x $100 \%=91,67 \%$ Angka tersebut termasuk ke dalam kategori Sangat Baik. Berdasarkan tabel di atas dapat diperoleh gambaran bahwa secara keseluruhan dari penilaian Dosen pencak silat mencapai 28/36 x $100 \%=77,78 \%$ dalam kategori baik. 


\section{Kelayakan Model Secara Empirik}

Berdasarkan hasil validasi dari pelatih pencak silat dan dosen pencak silat dan setelah dilakukan perbaikan sesuai saran yang diberikan, maka selanjutnya adalah melakukan uji coba. Uji coba dilakukan di dalam proses latihan ekstrakulikuler pencak silat di SMP N 2 Plumbon. Siswa diberi angket dan diminta untuk menilai tingkat kesulitan item latihan. Hasil angket penilaian siswa dalam uji coba 10 orang penulis bisa memaparkan bahwa secara keseluruhan nilai yang diperoleh dari 10 siswa ialah 93 yang dimasukan kedalam rumus $F=$ f/N x $100 \%$ menjadi $93 / 120 \times 100 \%=77,50 \%$ dalam kategori baik. Hasil rekap penilaian angket 10 siswa dapat disajikan dalam dalam Tabel 2 berikut:

Tabel 2

Hasil Rekap Nilai Angket Siswa Dalam Uji Coba 10 Siswa.

\begin{tabular}{|c|c|c|c|c|c|c|c|}
\hline \multirow{2}{*}{ No } & $\begin{array}{c}\text { Item } \\
\text { Model }\end{array}$ & \multicolumn{2}{|c|}{ Sulit } & \multicolumn{2}{c|}{ Sedang } & \multicolumn{2}{c|}{ Mudah } \\
\hline 1 & I & 0 & $0 \%$ & 2 & $20 \%$ & 8 & $80 \%$ \\
\hline 2 & II & 0 & $0 \%$ & 2 & $20 \%$ & 8 & $80 \%$ \\
\hline 3 & III & 3 & $30 \%$ & 7 & $70 \%$ & 0 & $0 \%$ \\
\hline 4 & IV & 2 & $20 \%$ & 8 & $80 \%$ & 0 & $0 \%$ \\
\hline \multicolumn{2}{r|}{ Jumlah } & 5 & $12,5 \%$ & 19 & $47,5 \%$ & 16 & $40 \%$ \\
\hline
\end{tabular}

Hasil angket yang di isi oleh 10 siswa tentang pengembangan model SIBAKOL IBFA (Simak Bayangkan Koreksi dan Lakukan Ibnu Faisal adalah 12,5 \% siswa menjawab sulit, 47,5 \% siswa menjawab sedang dan 40, \% siswa menjawab mudah.

Selanjutnya sesuai prosedur pengembangan model yang mengharuskan uji coba skala yang lebih besar yaitu dari hasil angket penilaian siswa dalam uji coba 20 siswa bahwa secara keseluruhan nilai yang diperoleh dari angket 20 siswa 185 yang dimasukkan ke dalam rumus $\mathrm{F}=\mathrm{f} / \mathrm{N} \times 100 \%$ menjadi 185/240 x $100 \%=77,08 \%$ dalam kategori baik. Hasil rekap penilaian angket 20 siswa dapat disajikan dalam tabel 3 berikut:

Tabel 3

Hasil Rekap Nilai Angket Siswa Dalam Uji Coba 20 Siswa.

\begin{tabular}{|c|c|c|c|c|c|c|c|}
\hline \multirow{2}{*}{ No } & $\begin{array}{c}\text { Item } \\
\text { Model }\end{array}$ & \multicolumn{2}{|c|}{ Sulit } & \multicolumn{2}{c|}{ Sedang } & \multicolumn{2}{c|}{ Mudah } \\
\hline 1 & 1 & 0 & $0 \%$ & 5 & $25 \%$ & 15 & $75 \%$ \\
\hline 2 & II & 0 & $0 \%$ & 9 & $45 \%$ & 11 & $55 \%$ \\
\hline 3 & III & 3 & $15 \%$ & 11 & $55 \%$ & 6 & $30 \%$ \\
\hline 4 & IV & 5 & $25 \%$ & 15 & $75 \%$ & 0 & $0 \%$ \\
\hline \multicolumn{2}{|c|}{ Jumlah } & 8 & $10 \%$ & 38 & $50 \%$ & 32 & $40 \%$ \\
\hline
\end{tabular}

Hasil angket yang di isi oleh 20 siswa adalah $10 \%$ siswa menjawab sulit, $50 \%$ siswa menjawab sedang dan $40 \%$ siswa menjawab mudah. 


\section{Diskusi Hasil Penelitian}

Pembelajaran gerak merupakan bagian dari pembelajaran secara umum, sebagai bagian dari pembelajaran. Belajar gerak mempunyai tujuan tertentu. Tujuannya adalah untuk menguasai berbagi keterampilan gerak dan mengembangkannya agar keterampilan gerak yang dikuasai bisa dilakukan untuk menyelesaikan tugas-tugas gerak untuk mencapai sasaran tertentu. Saputra (2008) mengungkapkan bahwa: "Pembelajaran gerak adalah mengkaji proses yang tercakup dalam mendapatkan dan menyempurnakan keterampilan gerak".

Berdasarkan kajian secara teoritis dan pengalaman selama penelitian, penulis menemukan hal-hal yang penting dalam penelitian pengembangan ini antara lain: Dengan urutan latihan yang tepat (latihan jurus terlebih dahulu dilanjutkan latihan fisik) siswa bisa lebih berkonsentrasi pada latihan jurusnya, yang ujungnya penyerapan materi latihan bisa optimal. Dimana sebelumnya penyerapan materi latihan tidak sepenuhnya bisa diterima siswa dikarenakan siswa sudah merasa lelah yang disebabkan oleh latihan fisik.

Latihan jurus tunggal baku walaupun secara kasat mata berbentuk aktifitas fisik, akan tetapi pada awal-awal penguasaan jurus tersebut harus diawali dengan penguatan secara kognitif, yang dalam penelitian ini siswa harus dioptimalkan dengan cara memperhatikan/menyimak gerakan yang harus dikuasai. Jumlah gerakan jurus yang akan disampaikan juga harus diperhatikan, jumlah gerakan yang terlalu banyak akan menyulitkan siswa merekam dalam memori mereka, sebaiknya 5-7 gerakan jurus saja. Hal ini berkaitan dengan motivasi belajar. Dengan penerapan model ini motivasi belajar bisa terjaga akibat dari seringnya siswa merasa berhasil menguasai jurus tersebut.

\section{Daftar Pustaka}

Kriswanto, E. S. (2015). Pencak Silat: Sejarah Perkembangan, Teknik- Teknik Dan Pengetahuan Dasar Pencak Silat : Yogyakarta : Pustaka Baru Press.

Lubis, J \& Wardoyo, H. (2013). Pencak Silat Edisi Kedua: Jakarta: Raja Grafindo Persada.

Nugroho, A. (2011). Diktat Pedoman Latihan Pencak Silat. Yogyakarta: Fakultas Ilmu Keolahragaan UNY.

Mahendra, A. (2007). Modul Teori Belajar Mengajar Motorik. Bandung: FPOK Universitas Pendidikan Indonesia.

Mulyana. (2013). Pendidikan Pencak Silat: Membangun Jati Diri dan Karakter Bangsa. Bandung: PT Remaja Rosdakarya

Saputra, Y. M. (2008). Perkembangan Motorik. Bandung: FPOK Universitas Pendidikan Indonesia Sugiyono. (2018). Metode Penelitian Kuantitatif Kualitatif dan $R \& D$. Bandung: CV Alfabeta. Suryadin, T. (2018). Perbandingan Pengaruh Latihan Tendangan Menggunakan Handbox Bergerak Dan Tidak Bergerak Terhadap Kecepatan Tendangan Dalam Olahraga Pencak Silat Kategori Tanding. Jurnal Educatio, vol 4, no. .. Tersedia di http://jurnal.unma.ac.id/index.php/edc/article/view/1284 (online) 